\title{
INCOME TAX ASPECTS OF A CORPORATION'S DEALINGS IN ITS OWN SHARES
}

\section{Calvin H. Rankin $\dagger$}

One of the questions which has provoked much discussion recently among those interested in the nature and determination of corporate income, from an accounting as well as an income tax standpoint, ${ }^{1}$ is the problem of whether or not a corporation may realize income or loss from the purchase and subsequent sale of its own shares. ${ }^{2}$

The decision of the Supreme Court in the case of Helvering $v$. $R$. J. Reynolds Tobacco Company ${ }^{3}$ had been awaited with great interest in the hope that the opinion rould supply a ruling of such a nature as would end the controversy on this still unsolved question. But the Supreme Court found it unnecessary to decide, or even discuss, whether income or loss could arise out of such dealings by a corporation in its own shares, and instead added another case to the long series relating to the effect which should be given to Treasury Department Regulations in the interpretation of the income tax laws.

This aspect of the decision has received its full share of attention in recent legal publications, ${ }^{4}$ and throws no light, except in one respect, on the real problem which still remains unsolved. The decision necessarily implies that the former Treasury Regulation to the effect that

† B. S. in Econ., 1923, LL. B., I932, University of Pennsylvania; Assistant Profcssor of Accoruting, Wharton School, University of Pennsylvania; author, Trcasury Stock-A Source of Profit or Loss9 (19:0) 15 Accro. REv. 71 ; member of the Philadelphia Bar.

1. May, Recent Opinions on Dealings in Treastery Stock (1938) 66 J. Accrcy. 17; Montgomery, Dcalings in Trcas:try Stock (1938) 65 J. Acctcr. 466; Rankin, Treasury Stock-A Source of Profit or Loss? (1940) 15 Acctg. Rev. 7I; Watson, Principles Related to Trcastry Stock (1938) A Mremicas IsistituTe of Accountants, Fifty-First Annual Ifeeting Procefings. Nates, Federal Taxation of Treasury Stock Transactions (1938) 6 U. of CHI. L. Rev. 92; Taxability of Transactions by a Corporation in Its Ozm Stock (1937) 47 Y.LE L. J. III; Dcalings in Treasury Stock (1938) $66 \mathrm{~J}$. Accrcy. 112; Profits or Losses on Trcasury Stock (1938) $65 \mathrm{~J}$. Acctcy. 417.

2. It may be questioned whether, strictly speaking, a corporation should ever be said to "purchase" or "scll" its own shares. However, the terminology used herein must be, to a large extent that of the inceme tax law and Treasury Regulations. It is realized that definitions vary for many of the terms employed herein, such as "capital," "proprietorship," "net assets," "treasury stock," "income," "profits," "gains," "earnings," etc. Space limitations and a desire to aroid ponderosity are the only excuses for using such terms without an attempt at definition. It is hoped that the lack of precision in definition and ise will not cause too much misunderstanding.

3. 306 U. S. I 10 (1939).

4. Alvord, Treasury Regulations and the IVilshire Oil Case (1940) 40 CoL L. RFv. 252; Brown, Regnilations, Recnactment and the Recune Acts (1941) 54 Harv. L. Rev. 377; Griswold, A Summary of the Rrgulations Problem (1941) 54 HARv. L. REv. 398; Paul, Use and Abuse of Tax Regulations in Statutury Construction (1940) 49 YALE I. I. G60; Surrey, The Scope ard Effect of Trcasury Regulations under the Income, Estate, and Gift Tares (1940) \&8 U. of PA. L. Rev. 556. 
"If the corporation purchases any of its stock and holds it as treasury stock, the sale of such stock will be considered a capital transaction and the proceeds of such sale will be treated as capital and will not constitute income of the corporation. A corporation realizes no gain or loss from the purchase or sale of its own stock." \&

is not contrary to the terms of the income tax law, at least in so far as it excludes from the concept of taxable income the excess of the proceeds of the sale of "treasury stock" over its cost. This, of course, does not necessarily imply that a regulation to the opposite effect would not have been considered an equally proper construction of the law.

It is the purpose of this article to consider the circumstances under which the decided cases have found income or loss to have been realized by a corporation from transactions in, or involving its own shares, and to show, if possible, a pattern which will reconcile these cases with the generally accepted concept of the relationship of a corporation and its shareholders and with the nature of corporate income.

\section{The Corporation as an Accounting and Taxable Entity}

The traditional viewpoint that a corporation is being operated for the benefit of its owners, the shareholders, and that all profits distributed should go to them has been the basis for the development of the concept of eorporate income. In general, corporate income should increase the amount avaikable for distribution to the proprietors.

From the standpoint of the necessity of additional legal restraints on the exercise of the customary powers of the corporate directors, it has been nccessary to recognize that

"The property owner who invests in a modern corporation so far surrenders his wealth to those in control of the corporation that he has exchanged the position of independent owner for one in which he may become merely recipient of the wages of capital." 7

But the possibility of the divorcement of corporate ownership from control, should not be allowed to confuse questions of corporate income.

Perhaps the distinction between a shareholder and a creditor of a corporation is a narrow one, but it is fundamental to the accounting concept and the statutory definition of taxable corporate net income. Both may be recipients of the wages of capital, but interest paid to the creditor is an allowable deduction in computing taxable net income

5. U. S. Treas. Reg. 74 , Art. 66.

6. Sce MrAgILL TAX AELE INCOME (1936) 23.

3. $C$ f. id. at 333 . 
while dividends to shareholders are not deductible. The discharge of a creditor obligation at less or more than its book value generally results in corporate gain or loss. ${ }^{8}$ However, it does not necessarily follow that corporate gain or loss may result from the similar discharge by the corporation of its obligation to account to a shareholder for his share of the net assets.

One of the earliest conventions, forming the foundation of accounting practice and procedure, is that of the impersonal accounting entity, the business enterprise. The accounting records are kept and statements prepared for that entity, something separate and distinct from the persons who furnished the funds for the conduct of the business enterprise. With the advent of the corporate form of business, this artificial concept became a legal fact.

The accounting entity concept has always recognized an essential difference in the nature of the relationship of the creditor and the proprietor claims, because of the difference in their respective legal rights; and the concept makes provision for interest on creditor's claims before determining the net income of the enterprise, which net income in turn is added to the amount representing the beneficial interest of the proprietor. The amount "due" the proprietor, therefore, is the amount contributed, plus or minus any adjustments by way of income or loss, less any amounts distributed to the proprietor. ${ }^{10}$

No change in this accounting concept was necessary to adapt it to the business enterprise conducted in corporate form, except that, because of legal restrictions on the withdrawal of contributed capital, the amount of the proprietorslip equity contributed by the shareholders is kept separate from the amount of the proprietorship equity accumulated by way of income. ${ }^{11}$

8. Darrell, Discharge of Indebtedness and the Federal Income Tax (1940) 53 HARv. L. Rev. 977, 999; Surrey, The Reicme Act of 1939 and the Income Tax Treatment of Cancellation of Indebtedness (1940) 49 Y ALE L. J. 1153. However, where the discharge of indebtedness still leaves the corporation insolvent so that a benefit to the shareholders does not result, the cases have held that no corporate income has been realized. See Highland Farms Corp., 42 B. T. A. No. 195, Nov. 27, 1940, and cases cited therein.

9. Gillican, Account:avg Concepts of Profit (1939) 38-65; Littleton, AccountING Erolution to 1900 (1933) 194.

10. It is recognized that corporations may receive "gifts" from those outside the proprietorship interest and which increase proprictorship. As to whether such "gifts" would be income, if not specifically cxclucled by statute, see MAGIL., TAXABLE INCOME (1936) 357; Paul, Studies in Federal Taxation (1938) 158, 163; I PaUl aNd

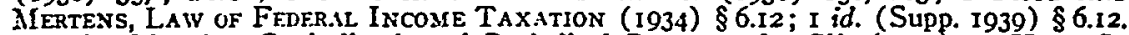
See also Mfaguire, Capitalization of Periodical Payments by Gift (I920) 34 HARv. L. REv. 20. Contributions by shareholders are not corporate income. Auto Strop Safety Razor Co. v. Commissioner of Internal Revenue, 74 F. (2d) 226 (C. C. A. 2d, 1934); Orcgon-Washington R. R. and Navigation Co., $25 \mathrm{I}$ Fed. $21 \mathrm{I}$ (C. C. A. 2d, 1918);874 Park Ave. Corp., 23 B. T. A. 400 (193I); I. T. 1469, I-2 Cun. Bull. IgI (Ig22).

II. Contributed capital is shown as capital stock and paid-in or capital surplus. Income is accumulated in earned surplus or undivided profits. 
In any of the accounting entities, sole proprietorship, partnership or corporation, amounts of capital contributed by the proprietorship interest are not income of the entity and, conversely, amounts distributed to the proprietorship interest, as such, do not represent losses.

The income tax law taxes the corporate entity on its income (with certain specific adjustments provided.by way of exclusions from income and limitations on deductions) and the balance of its income is taxed again to the shareholders when distributed either by way of dividend or liquidation. ${ }^{12}$

No completely satisfactory definition of income, corporate or otherwise, has ever been developed. The income tax cases show rather that the courts turn to the decisions for precedents, and, in the absence of such, exercise their independent judgment as to whether in "common understanding" 13 and consistent with the previous development of the general tax structure, a transaction can be said to result in income.

A review of the decided cases on the question of taxable income or deductible loss arising from a corporation's transactions in issuing, purchasing or otherwise acquiring its own shares, reflects the gradual development of a censistent treatment of all such transactions except one-the purchase and sale of "treasury shares."

\section{Judicial Developarent of Income Tax Aspects of Creation of Shares}

\section{A. Creation of Shares for Cash or Property}

The Treasury Department Regulations have always made it clear that the receipt by a corporation of the subscription price of its capital shares upon their original issuance does not give rise to taxable income or deductible loss, whether the issue price be in excess of, or less than, the par or stated value of the stock. ${ }^{14}$

This provision of the Regulations has seldom been questioned, ${ }^{15}$ despite the fact that, when sliares are already outstanding, the amount

12. Sce 5 Paul and Mertens, Law of Fejeral Incomf Taxation (I934) \$53.18; Ballantine, Corporate Personality in Income Taration (Ig21) 34 Ifarv. L. REv. 573; Finkelstein, The Corporate Entity and the Income Tax (1935) 44 YALE $\mathrm{L}$ J. 436.

13. United States v. Kirby Lumber Co., 284 U. S. I, 3 (I93I) ; Irwin v. Gavit, 268 U. S. I6r, 166 (I925) ; Merchants Loan and Trust Co. v. Smictanka, 255 U. S. 509, 519 (1921) ; Fisner v. Macomber, 252 U. S. 189, 206 (1920).

14. U. S. Treas. Reg. 103, § 19.22 (a) -16 (I940) and similar provisions of prior Regulations.

15. This argument was indirectly considered in one court case. In Carter Hotel Co. v. Commissioner of Internal Revenuc, 67 F. (2d) 6.12 (C. C. A. $4^{\text {th, 1933), the }}$ corporation had issued preferred shares at $75 \%$ of their present market and liquidating value with the option to redeem within two years at the issue price. It claimed a loss in the year in which the right to redeem expired. The court, in denying the loss deduction in that year, pointed out that the cntire transaction may have had some effect upon the value of the holdings of the common stockholders, but the corporation itself, which 
received for additional shares may affect the value of the present shareholders' interests either favorably or adversely. Even if shares are issued at their reasonable sale value to new shareholders, there will very probably be some change in the interest of the former shareholders from a liquidation standpoint, assuming that it is possible to determine a liquidating value prior to actual liquidation. The market value of shares, depends not only upon the book and liquidating value of assets, but also upon past and prospective earnings and the demand for capital in general. It will rarely coincide with either book or liquidating values of the former outstanding shares. ${ }^{16}$

It is important to note that the almost inevitable change in the value of the former shareholders' interests, produced by the issuance of adjitional shares, is not made the basis for a gain or loss to the corporate entity. All the corporation does is to increase the proprietors' capital contributions. The shifting of shareholders' interests in that total proprietorship equity is not a source of corporate gain or loss.

The rule that a corporation cannot realize a gain or loss because of the amount reccived in the creation of its shares is also applied to the conversion of its bonds, issued at a discount, into shares of a par or stated value equal to the maturity value of the bonds. ${ }^{17}$

These cases have been argued on the theory that the unamortized bond discount becomes an allowable deduction at the time of conversion because the issuance of shares of a par value equal to the face of the bonds constitutes payment of the face value of the bonds. The claimed deduction is uniformly disallowed on the ground that, from the standpoint of the corporation, the amount received on the sale of the bonds, plus discount amortized to the date of the exchange, represents the amount received by the corporation on the subsequent issuance of the shares. It is equivalent to the issuance of shares at a discount, a transaction which does not produce a corporate loss. ${ }^{18}$

is the taxpayer here, sustained no loss of any character. $C f$. Corning Glass Works v. Commissioner of Internal Revenue, 37 F. (2d) 798 ( $A$ pp. D. C. Tg29), cert. denied, 281 U. S. 742 (1930).

I6. The price at which additional shares can be sold in the market may not even be the same as the fair market value of shares iminediately prior to the proposed creation of additional shares, since the proposed crcation itself, may affect the sale value of the shares about to be created.

17. Chicago, Rock Island \& Pacific Ry. v. Commissioner of Internal Revenue, 47 F. (2d) 990 (C. C. A. 7th, 1931), cert. denied, 284 U. S. 618 (1931) ; Liquid Carbonic Corp., 34 B. T. A. Irgr (1936); 375 Park Ave. Corp., 23 B. T. A. 969 (I931); T. D. 4603, XIV-2 CuMr. BurL 58 (I035) ; I. T. 2347, VI-1 Cum. Burt. 86 (1927). See also G. C. M. $9674, \mathrm{X}-2$ CUM. BULL. 354 (1931). But, of course, when bonds were actually retired in cash at face value, from the proceeds of the issue of shares, any unamortized bond discount constitutes an allowable deduction. National Tile Co., 30 B. T. A. 2 (1934).

18. The market value of shares issued is often used as a measure of the value of assets acquired,. or of services rendered, when payment is made in the corporation's 


\section{B. Cration of Shares in Payment of Compensation}

The statement that a corporation realizes no gain or loss on the original issuance or sale of its shares is correct only in so far as it refers to the amount but not the nature of the consideration received. This is shown by the line of cases holding that if the slzares are issued as compensation or bonus to employees, a deduction in the amount of the compensation or bonus is allowed to the corporation. ${ }^{19}$ While none of the decided cases have denied this deduction, the confusion arising where shares are issued as compensation or bonus is shown in several dissenting opinions in the Board of Tax Appeals.

In Farming Corporation there were six members who dissented as follows:

"I cannot agree that the corporation either paid or incurred an ordinary and necessary expense in any amnunt by issuing stock. It paid out nciling and incurred no obligation to pay. It created a new interest in its assets and business, and this did not affect its incone any more than the possibility of dividends. or liquidating distributions ever do." 20

Iater in Commercial Investmunt Trist Corporation, ${ }^{21}$ where the corporation gave its employees the right to purcliase shares of its $c_{3}$ ital stock at less than fair market value and was allowed this difference as a deduction, there were two dissenting opinions. The first pointed out that the corporation had spent nothing:

"What then serves to reduce its income? Nothing, unless the relistribution of share interests can be said to do so."

The cther dissenting opinion argues:

"Other stockholders of the petitioner are the only ones adversely affected by the issuance of additional stock at less than its fair market value. Thereafter they have to be content with a

own shares. No such measure should be applicd here when the amount of the considcrition received by the corporation las been previously and independently fixed in collars.

19. Indianapolis Glove Co. v. United States, 96 F. (2d) 816 (C. C. A. Tth, 1938); A! :r-Sullivan Lumber Co. v. Commissioner of Internal Rcrenue, $57 \mathrm{~F}$. (2d) 3 (C. C. A. Sth, IS,32); Hudson Jlutor Car Co. v. United States, 3 F. Supp. 834 (Ct. Cl. 1933); Chrysler Co.p., 42 B. T. A. ;55 (ro,o); Filcrtric Storage Battery Co., 39 B. T. A. I2I (1930) ; Ritter I.unibrr Co, 30 B. T. A. 231 (I934); Package Machinery Co., 28 B. T. A. 98o (r933); Commircial f.ivestment Trust Corp., 28 B. T. A. I43 (1933), aff'd fer criar:, 74 F. (2d) 1115 (C. C. A. 21, 1035); Forest Products Chemical Co., 27 B. T. A. 638 (I93.3); ' Co., 12 B. T. A. I273 (Ig.3), tevd on othir grisds, $46 \mathrm{~F}$. (2d) 604 (App. D. C.

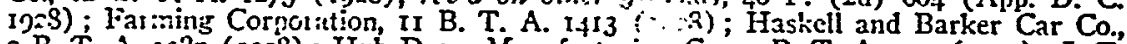
9 R. T. A. 1037 (1928); Hub Dress Manufacturin Co., I B. T. A. 197 (1924); I. T. 2204, 1938-2 CuM. Bull. 126; I. T. 2041, III-1 CUM. Bul. 392 (1924); I. T. II97, I-I CUM. BuLI. 260.

ํ. II B. T. A. I413 (1928).

2t. 28 B. T. A. 143 (1933). 
smaller share of the corporate distributions. But the income of the issuing corporation certainly is not reduced. Its assets are not reduced."

The attitude shown in these quotations fails to recognize that the corporation in issuing its own shares may be dealing with the prospective shareholder as a shareholder and at the same time as an employee who has rendered services. It looks only at one aspect of the transaction, the issuance of shares, and does not consider the nature of the consideration that must have been received.

It is true that no income or loss is actually created because of the amount received upon the issuance of shares, but the isstiance of shares may mark the time of the realization of loss which arose in the consideration received, namely, services already rendered. The market value of the shares issued may in some cases determine the amount of that income or loss.

In cases involving the issuance of shares in payment of compensation, if the corporation is on an accrual basis, an obligation and a deductible expense is incurred the moment that the services have been rendered and the amount of compensation has been agreed upon or is capable of determination. ${ }^{22}$ This deduction should not be disallowed for tax purposes merely because shares are issued in discharging the obligation. It is true that the total proprictorship remains unchanged, but this is solely because the decrease in earnings reflected in earned surplus is exactly offset by the contribution to capital of the same amount reflected in an increase in capital stock.

Expenses may be paid in shares, and the cost is just as real as the cost of assets acyuired by the issuance of shares. ${ }^{23}$ The expense so paid constitutes a current deductible expense; the cost of the asset, if depreciable, will constitute a similar deduction, only apportioned over the life of asset. If the compensation is not unreasonable in amount when added to compensation previously paid, it becomes at the time of accrual or payment an allowable deduction.

While the right to the deduction is now unquestioned, there is atill considerable confusion as to the determination of the amount of the deduction. When the shares are given outright as a bonus after the services have bcen rendered, the fair market value of the shares at the

22. Forest Products Chemical Co., 27 B. T. A. 638 (I933).

23. Hazeltine Corp. v. Commissioner of Internal Revenue, $89 \mathrm{~F}$ (2d) 513 (C. 'C. A. 3d, 1937) ; Pierce Oil Corp., et al., 32 B. T. A. 403 (1935); Holmby Corp., 28 B. T. A. Io92 (1933), aff'd, 83 F. (2d) 548 (C. C. A. 9th, I936); Ambassador Petroleum Co., 28 B. T. A. 868 (1933), revid on ollec grounds, 8I F. (2d) 474 (C. C. A. gth 1936) ; Stires Corp., 28 B. T. A. I (1933). If the fair market value of the shares cannot be asccrtaired then the fair market value of the assets acquired is taken as its equivalent. Gillette Rubber Co., 3I B. T. A. 483 (1934). 
time of delivery generally fixes the amount, ${ }^{24}$ but the deduction is limited to book value if the corporation can redeem them at book value. ${ }^{23}$ When the employer and employee both pay in to an employee ownership plan, the deduction is measured by the amount of the corporation's actual payment to the fund and is not affected by fluctuations in the market value of the stock purchased and delivered by the fund. ${ }^{28}$ When the amount of the compensation has been determined in dollars and then paid in shares purchased by the corporation the amount of the deduction is limited to the dollars of compensation determined, even though at the time of delivery to the employee the shares purchased by the corporation had appreciated in value.27

The fact that the amount of the compensation deduction may or may not be the fair market value of the shares issued, emphasizes the fact that the loss is inherent in the nature of the consideration, and not the shares issued. When the amount of compensation for services has been determined the amount of the deduction is fixed. Its payment in shares of the corporation then falls within the general rule that a corporation realizes no gain or loss because the consideration received on the original issue of its own shares is more or less than the par or market value of the shares issued.

\section{Forfeited Share Subscriptions}

Even where a subscribing shareholder forfeits the installments paid, the courts have uniformly held that no corporate income results. ${ }^{28}$ The reasoning of the decisions is that the payments are being made to provide capital for the corporation and are capital receipts as distinguished from income.

These decisions throw a revealing light on the courts' concept of the nature of corporate income. If the corporate entity is viewed as a business enterprise conducted for the benefit of the kemaining shareholders, such forfeitures might well be considered corporate income. But it appears that the corporate entity is considered as being con, dicted for the benefit of all shareholders, including subscribers to

24. Indianapolis Glove Co. v. United States, 96 F. (2d) 816 (C. C. A. 7th, 1938); Al-2er-Sullivan Lumber Co. v. Commissioner of Internal Revenue, $57 \mathrm{~F}$. (2d) 3 (C. C. A. jth, I932); Package Machinery Co., 28 B. T. A. 980 (I933).

75. Ir uriton Mrotor Car Co. v. United States, 3 F. Supp.834 (Ct Cl 1933).

25. Electric Storage Battery Co., 39 B. T. A. I2I (1939).

27. Liquid Carbonic Corp., 34 B. T. A. I191 (1936) ; cf. Chrysler Corp, 42 B. T. A. 705 (1940).

28. Terminal Grain Corp. v. United States, 22 Am. Fed Tax Rep. I290 (N. D. Iowa, I938); Realty Bond and Mortgage Co. v. United States, I6 F. Supp. 771 (Ct Cl. 1936); Industrial Loan and Investment Co. I7 B. T. A. 1328 (1929); Illinois Rural Credit Ass'n, 3. B. T. A. 1178 (1926) ; Port City Stockyards Co., B. T. A., memo. op, Docket No. 87174 (1938); cf. Commissioner of Internal Revenue v. Inland Finance Company, 63 F. (2d) 896 (C. C. A. 9th, 1933). But see 50 HARv. L. Rev. 697 (i937)

(criticizing these decisions). 
shares. Corporate profit is something in addition to the total proprietorship capital paid in by shareholders or prospective shareholders.

From the shareholders' standpoint, the present loss of the forfeiting subscriber or shareholder becomes the ultimate gain of the remaining shareholders. There is a shifting of interests in the capital fund between the contributors to that fund, but an eventual equality of income and loss on the part of the entire group of subscribers and shareholders which does not give rise to any corporate income. It is solely because the one forfeiting his payments was a contributor to the corporation's capital that the forfeiture does not result in income. The forfeiture of a deposit or payment made for any other purpose would have produced income. ${ }^{29}$

Judicial Development of Income Tax Aspects of Purchase and

\section{Liquidation of Shares}

\section{A. Complete Liquidation}

The complete liquidation of a corporation's own shares in cash obviously presents no income tax problems to the corporation. However, when complete liquidation in kind takes place it could be argued that the distribution of assets appreciated or depreciated in value constitutes an exchange or such a disposition as would cause the realization of that gain or loss by the corporation. ${ }^{30}$

The Regulations have answered this question as follows:

"No gain or loss is realized by a corporation from the mere distribution of its assets in kind in partial or complete liquidation, however they may have appreciated or depreciated in value since their acquisition." 31

The decisions, in cases of complete liquidation, have all accepted this regulation as a proper interpretation of the law without argument or discussion. ${ }^{32}$ The regulation has even been held controlling in a

29. Installment payments forfeited by purchasers of corporation's bonds held income to corporation. First National Bank of Manchester, 3 B. T. A. 751 (1926).

30. The use of such property to discharge a creditor obligation causes a realization of the gain or loss. Bacon Mclfillan Veneer Co., 20 B. T. A. 556 (1930); Callanan Read Improrement Co., 12 B. T. A. 1109 (1928).

For a discussion of the effect of distribution in kind in complete liquidation as affecting the realization of corporate gain or loss see Darrell, Corporate l-igridations and the Fod. ral Income Tax (Ig-1) $89 \mathrm{U}$. of PA. L. Rev. 007,920 , supra in this issue.

3I. U. S. Treas. Reg. 103, \$ I9.22 (a)-2I (19.40) and similar provisions of prior regulations. But in U. S. Treas. Reg. 69, Art. 548 (Reventue Act of 1926) and prior regulations, the provision was limited to distribution in kind upon "dissolution."

32. United States v. Gendron Wheel Co., 100 F. (2d) 57 (C. C. A. 6th, 1938); Gcorge S. Towne, et al., 35 B. 'Г. A. 141 (1036); Stockyards Bank of Cincinnati, 25 B. T. A. 064 (1932) ; Merchants Bank and Trust Co., 21 B. T. A. 824 (1930); W. P. Fox \& Sons, Inc., 15 B. T. A. 115 (1929); Afeurer Steel Barrel Co., II B. T. A. 584, aff'd per curiam, 35 F. (2d) 1019 (C. C. A. 2d, 1929); Rubay Co., 9 B. T. A. r33 (I92\%) : Hollenberg Music Co., 6 B. T. A. 421 (IV27); of. General Utilities and Opcrating Co. v. Helvering, 296 U. S. 200 (I935) (dividend in kind does not cause realization of appreciation). 
case where a corporation had chosen the installment method of deferring the reporting of realized profits on sales and later distributed the installment obligations in kind in complete liquidation, possibly as strong a case for realization of income on complete liquidation as can be presented.88

\section{B. Receipt aind Partial Liquidation of Shares in Connection with Sales or Exchanges of Property and Payment of Indebtedness}

It has never been suggested that a corporation did not realize exactly the same gain or loss from a bona fide cash sale of its property or services to one of its shareholders, as it did from a sale to any other purchaser. But it was at one time thought that if the corporation should receive its own shares in payment, the income or loss otherwise present could not be realized.

In its early decisions the Board of Tax Appeals decided that a finding of corporate gain or loss in such cases was at variance with the regulation providing that a corporation realizes no gain or loss from the purchase of its own stock. ${ }^{34}$ This regulation, however, was intended to apply only to the possibility of gain or loss due to the fact that the consideration paid by the corporation might be more or less than the amount received from the issuance of the shares, or the present book, market, or liquidating value of the shares. The non-recognition of gain or loss inherent in the consideration itself was not intended, and the regulation as so construed is indefensible.

Later the Board appeared to recogize that this regulation had no reference to the problem of the realization of gain or loss from sales of assets paid for in the corporation's own shares, and allowed losses in two cases. 35

But finally, in considering transactions which would have resulted in corporate income if settled in cash, the Board was struck by the fact that if the corporation received its own shares in payment for services,

33. Smart Farm Co., 25 B. T. A. 689 (1932) ; Virginia Beach Golf Course Annex Corp., 23 B. T. A. 1170 (193I). The Committee Reports on $\$ 44$ (d) of the Revenue Act of 1928 , which rectified this oversight, recognized that the transfers of installment obligations in liquidation, or by gift, or at death "ordinarily do not give rise to gain." I939-I Cux. BuLI. 394, 425 .

34. I.iberty Agency Co., 5 B. T. A. 778 (1926); Union Trust Co. of New Jersey, i2 B. T. A. 688 (1928); Walville Lumber Co., 12 B. T. A. 152 (1928), revd, 35 F. (2d) 445 (C. C. A. gth, 1929). This undoubtedly accounts for the omission of this provision in the amendment of the Regulations in 1934 by T. D. 4430, XIII-I CU3s. BurL. 36 (1234) ; in turn resoked by T. D. 4895, 1939-1 CuMr. BuLr 225. U. S. Treas. Reg. 45, Art. 542 (1918 Act) and U. S. Treas. Reg. 62, Art. 543 (I921 Act) provided "A corporntion realizes no gain or loss on the purchase of its own stock." In subsequent regulations it was marje to read, "purchase or sale." U. S. Treas. Reg. 65, Art. 543 (1924 Act) ; U. S. Treas. Reg. 69, Art. 543 (1926 Act); U. S. Treas. Reg. 74, Art. 66 (1928 Act); U. S. Treas. Reg. 77, Art. 66 (1932 Act).

B. T. A. 1059 (1929). 
the net assets did not increase, and where property of the corporation was exchanged for shares the net assets actually decreased. That there could be income and at the same time no change, or even a decrease in net assets, seemed a contradiction, and convinced the Board that its early decisions were correct. ${ }^{36}$ But this is true in all such cases since the asset momentarily created, the obligation to pay for the services or for assets sold, is the very asset distributed to the shareholder when his shares are liquidated. The significant fact is that the corporation has been able to give the retiring shareholder a consideration equal to the value of his shares without to the same extent reducing its net assets.

The Board's approach to the problem would always justify a loss where property depreciated in value was exchanged for shares. The decrease in net assets would more than account for a loss. And, moreover, this test had already been discarded by the Board, in cases involving the payment of expenses by the issuance of shares. There, despite the fact that the net assets are not decreased, the expense deduction is allowed.

It is not the receipt of its own shares which creates the income or loss. It is rather the rendering of services by the corporation or the sale of assets appreciated or depreciated in value which creates the income or loss. The corporate income or loss was inherent in the assets sold or the services rendered, not in the shares received. That income or loss should be recognized when realized, even if the medium of payment is the corporation's own shares which cease to be property when received by the corporation.

If a sale of corporate assets is the real nature of the transaction, the receipt of its own shares in payment, may be the event which marks the time of the realization of the income or loss on the sale. But it is entirely possible for the income or loss in question to be realized upon the execution of an enforceable contract of sale. ${ }^{37}$ In such a case it should be clear that the income or loss, already actually realized, should not be eliminated because the corporation's shares are later accepted as a medium of payment.

The courts, in every case presented, have refused to be misled by the fact that a corporation's own shares were involved, and have held

36. Holiston Brothers Co., 21 B. T. A. 804 (1930) ; Woods Machine Co., 21 B. T. A. $8 \mathrm{in}$ (1r.30), rev'd, 57 F. (2d) 635 (C. C. A. Ist, I932), cert. denied, 287 U. S. 613 (I932); Schiller Piano Co., 23 B. T. A. 376 (I93I), rej'd, 58 F. (2d) ro85 (C. C. A. ;th, 1932): Boca Ceiga Development Co., 25 B. T. A. 941 (1932), reo'd, 66 F. (2d) 1004 (C. C. A. 3d, 1933).

37. Commissioner of Internal Revenue v. Dashiell, 100 F. (2d) 625 (C. C. A. 7th, I938); C. B. Ferree v. Commissioner of Internal Revenue, $84 \mathrm{~F}$. (2d) I25 (C. C. A 3d, 1936); Ruml v. Commissioner of Internal Revenue, 83 F. (2d) 257 (C. C. A. 2d, 1936); Dee Furey Mott. 35 B. T. A. 195 (1936), affd per curiam, 103 F. (2d) 1009 (C. C. A. 6th, 1939); Francis S. Appleby, 3I B. T. A. 533 (1934). But not as to gains when the taxpayer is on a cash basis, Harden F. Taylor, 43 B. T. A. No. 78, Feb. 12 , 194 I. 
that the income or loss was realized. ${ }^{38}$ The decision of the Circuit Court of Appeals for the First Circuit in the case of Commissioner $v$. $S$. A. Woods Machine Company ${ }^{39}$ temporarily marked the end of the Board's vacillation. ${ }^{40}$

In the Woods case the taxpayer corporation had sued another corporation for damages for the infringement of a patent. It obtained a decree with the usual order of reference to ascertain damages and profits. The parties agreed upon a settlement which involved the relinquishment to the Woods Company of shares of the Woods Company's stock, owned by the infringer. The Board still argued that the Woods Company could not have income because, when the transaction was completed, it owned no property which it did not own before.

The Circuit Court of Appeals recognized that the case involved more than the mere question of gain or loss on the purchase of shares and developed the "real nature of the transaction" test (which became a part of the amended regulation), and held that income had been realized. ${ }^{41}$

But a more difficult problem still remains. The Regulations since r928, have provided that a distribution of property in kind in partial liquidation shall not cause the appreciation or depreciation in value of such property to be realized by the corporation as gain or loss. ${ }^{42}$ This reflects a recognition of the necessity of finding a realizing event, a sale of assets by the corporation or such other disposition as is necessary to constitute realization.

As applied to pro-rata distributions, no problem is generally presented. But when the liquidation of the shares of only one of many shareholders is involved, the necessity for mutual agreement upon what assets will be accepted in exchange for the shares, often causes the transaction to appear to be as much an actual sale of assets as a partial liquidation of shares, and subject to conflicting rules. This problem has only added to the confusion already caused by the attempt to apply to such cases the regulation relating to the purchase by a corporation of its own shares.

38. See court's reversal of Board decisions in cases cited notes 34 and 36 supra. And also Altyne-Zcrk Co. v. Commissioner of Internal Revenue, $83 \mathrm{~F}$. (2d) 525 (C. C. A. 6th, 1936); Dorsey Company v. Commissioner of Internal Revenure, 76 F. (2d) 3.39 (C. C. A. 5th, 1935), cert. denicd, 296 U. S. 539 (1935); Spear v. Heiner, 54 F. (2d) 134 (iW. D. Pa. I93I).

39. 57 F. (2d) 635 (C. C. A. Ist, 1932), cert. denied, 287 U. S. 613 (1932).

40. Houghton and Dutton Co., $26 \mathrm{~B} . \mathrm{T}_{\dot{1}} \mathrm{~A}_{.} 52$ (1932); Niagara Share Corp., 30 B. T. A. 668 (I934); Griswold Co., 33 B. T. A. 537 (I935); Allyne-Zerk Co., 29 B. T. A. I19. aff'd, 83 F. (2d) 525 (C. C. A. 6th, 1936); cf. Winston Brothers Co., 29 B. T. A. $005, a f^{\prime} d .76$ F. (2d) 38I (C. C. A. Sth, I935).

4I. The Circuit Court also was infucnced by the fact that the stock received was not cancelled and retired by the method povided by statute. This fact should have no bearing on this type of case, whatever cfiect it may have on distributions of assets appreciated in kind in partial liquidation. See notes 44 and 45 infra.

42. See note 31 supra. 
In two early cases, prior to this addition to the Regulations, the Board had considered the possibility that losses, claimed by corporations on the exchange of depreciated assets for their own shares, might be denied on the partial liquidation theory. ${ }^{42}$ Oddly enough, these were the only cases, prior to the Woods decision, in which the Board found that gain or loss could result from such transactions with a shareholder.

In the case of Dill Manufacturing Company the Board first applied this regulation. There the buying out of dissatisfied shareholders with assets depreciated in value was held to be a partial liquidation and a loss was denied, solely because the shares were cancelled and stated capital reduced in the manner provided by statute. In this case the Board indicated that if the shares acquired had been carried as "treasury stock," a partial liquidation would not have taken place and the loss would have been allowed. ${ }^{45}$

The courts have all applied the "real nature of the transaction" test, and in all cases have found that a sale took place which resulted in gain or loss. Where the facts indicate a sale the courts do not appear concerned as to the disposition of the shares received or the

43. In Behlow Estate Co., 12 B. T. A. 1365 (1928) the argument was discarded without discussion. In New Jersey Porcelain Co., I5 B. T. A. 1059 (1929) the fact that the shares were carried as "treasury stock" prevented a finding of partial liquidation.

4439 B. T. A. 1023 (1939). In Griswold Co, 33 B. T. A. 537 (1935) the taxpayer failed to produce evidence of the corporate intent or the disposition of the shares to support the claim that the transaction was a partial liquidation. In Hammond Iron Co., $4 \mathrm{I}$ B. T. A. 86 (1940) the Commissioner contended that the loss was precluded because a partial liquidation had taken place, despite the fact that the shares were not cancelled but carried as "treasury stock." The Board upheld the Commissioner but on the ground that the Reynolds' decision had reinstated the regulation to the effect that a corporation realizes no gain or loss on the purchase of its own stock. The application of that provision of the Regulations to such cases has been criticized, page 943 supro. See also Feltex Oil Corp., B. T. A. memo. op., Docket No. 100282 (1940), holding that eancellation of the shares was sufficient to cause a partial liquidation, even without a statutory reduction of stated capital as required by law.

45. For a further example of this test for partial liquidation see the recent cases as to whether the gain to a shareholder in a partial liquidation must be taken into account in full under $\$$ IIS (c) of the Revenue Act of 1934, and subsequent acts, instead of applying the capital gain and loss percentages provided in $\$ 11 \%$. If the shares acquired are carried as "treasury shares," there has been no partial liquidation. W. C. Robinson, 42 B. T. A. 725 (1940). Christopher Bauman, B. T. A. memo. op., Docket No. 95700 (1940) (even if later is was decided to cancel the shares); H. S. Berger, et al., B. T. A. memo. op., Docket No. 91000 (1939) ; A. B. Betz, B. T. A. memo. op., Docket No. 88828 (1939); William A. Smith, 38 B. T. A. 317 (1938). But if the shares are cancelled and not carried as "treasury shares" a partial liquidation has been effected. Will S. Fox v. Commissioner of Internal Revenue, 113 F. (2d) I13 (C. C. A. 3d, 1940); Amelia H. Cohen Trust, ef al., B. T. A. memo. op., Docket No. 98105 (1940); Ernest Alpers, B. T. A. memo. op.. Docket No. 97957 (1940) (even if shareholder thought the principal shareholder and not the corporation was the purchaser); William Schiffenhaus, B. T. A. memo. op., Docket No. 97580 (1940) ; Marie Hammans, B: T. A. memo. op., Docket No. 26504 (1940); Benjamin R. Britt, 40 B. T. A. 789 (1939), aff'd, IIA F. (2d) 10 (C. C. A. 4th, 1940) ; Wesley U. E. Terhune, 40 B. T. A. 749 (1939). See also Reg. 109, Excess Profits Tax, \$30.718-4 (I94I), no reduction in invested capital takes place until shares purchased are actually cancelled, if purchased for "investment." See also G. C. M. 15055, XIV-2 Cuis. BuLL 410 (I935) holding to the same effect for capital stock tax purposes. 
possibility of a partial liquidation. ${ }^{4 \theta}$ There appears to be no justification or necessity for making the cancellation of the shares acquired the sole test of realization of gain or loss. Realization should not depend on the disposition of the "proceeds." 47

When determining whether a partial liquidation has taken place, under the statutory definition, a strict compliance with the requirement of "cancellation or redemption" may be required. ${ }^{48}$ But the problem here is one of realization of gain or loss which has accumulated in an asset during the time it was held by a corporation. What constitutes a realizing event has not been so carefully defined in the law. ${ }^{19}$ A sale of the assets or their use in discharge of a creditor obligation causes a realization of that gain or loss. Their distribution in kind in complete liquidation does not cause a ralization. The transactions here considered lie somewhere between. The cases show that there can be no clear line of demarcation.

Having established the fact that the issuance or receipt of shares may be an event which narks the realization of gain or loss by the corporation, the effect of the distribution of assets to one or some of the shareholders in exchange for shares should be considered solely from the standpoint of whether under all the facts of each case the corporation has dealt with its appreciated or depreciated assets in such a manner as to constitute a realizing event. The name given the transaction, "sale" or "partial liquidation" or both, is immaterial.

\section{Partial Liquidation of Shares in Cash}

The Regulations once provided that a corporation realizes no gain or loss from the purchase of its own shares. The courts have never been asked to consider whether there is justification for a different income tax treatment of the purchase of shareholder "obligations" from that accorded the purchase of creditor obligations. 50 But the

46. See cases cited in notes 34,36 and 38 supra. But cf. Dorsey Company $\nabla$. Commissioner of Internal Revenue, 76 F. (2d) 339 (C. C. A. 5th, 1935), cert. dentied, 296 U. S. $=\$ 9$ (1935), in which the court did discuss this argument but held it inapplicable since the shares were not cancelled but held by the corporation for resale.

47. Walville Lumber Co. v. Commissioner of Internal Revenue, 35 F. (2d) 445 (C. C. A. 9th, 1929).

48. For a discussion of what constitutes partial liquidation under $\$ 115$ of the Corle sce Note, Income Ta.ration of Liquidating Dizidinds (I937) 47 Y ALE I. J. II 46.

49. For a discussion of the principles underlying realization sce MAgile, Taxarle IxcoNe (1936).

50. In Jewel Tea Co. v. United States, go F. (2d) 451 (C. C. A. 2d, I937) a corporation claimed a loss on the purchase of its preferred shares in the market at a premium. In denying the loss the court pointed out that it would have becn a logical and reasonable thing to treat only conmon shareholders as the owners of the business, who alone share the profits, and bondholders and preferrci shareholders as third parties, or outsiders, in dealings with whom corporate gain or profit may always be realized, but that the law has not seen fit to do this regarding only actual creditors as outside the corporate aggregation and the preferred shareholders as embarked, along with the common shareholders, as owners of the enterprise. 
elimination of that provision from recent Regulations may indicate that the Treasury Department now wishes to leave this question open. ${ }^{51}$ In fact, a much stronger case for corporate income or loss can be made out at the time of purchasing shares than at the time of their resale or original issuance.

It scems clear that if the corporation distributes to a common shareholder the exact liquidating value of his shares in cash, there is no income or loss to the corporation. The fact that the corporation may thus pay more or less than the amount received from the issuance of the shares is not significant. The difference may represent merely a recognition of the fact that corporate income or losses have since been realized.

Nor can the book figures, based to a large extent on the historical cost of assets and not including unrealized gains and losses, be used as a basis for computing corporate income or loss on the purchase of a shareholder "obligation." The creditor obligation is fixed in amount. The shareholder "obligation," at least to a common shareholder, is merely to account to him for his share of the net assets. The books merely reflect an arbitrary money value of the net assets, useful from an accounting standpoint for the allocation of the actual cost of the assets to annual accounting periods, but not purporting to measure the value in dollars of the shareholders' right to the net assets in liquidation.

While nothing but the roughest estimate of liquidating value can usually be given, prior to final liquidation, it is this value which must be used as the measure of corporate income or loss, if any, in the purchase of shareholder "obligations." If a corporation, because of the fact that market values are influenced by factors other than liquidating values, is able to purchase its own shares for less than their true liquidating value, should not this benefit to the remaining shareholders be considered corporate income? The result appears similar to that in the Woods and related cases where corporate income has been found to have been realized. The elimination of one shareholder, produces an increase in the liquidating values of the remaining shares. ${ }^{52}$

However, there is a material difference in the two cases. While in both the withdrawing shareholder received consideration equal to the market value of his shares, in the Woods case that consideration, from the corporation's standpoint, represcnted the yield from its capital assets, the income from the patent. That income had been actually

51. See cases cited note 34 supra.

52. Morcover the converse should be equally true. If the corporation to rid itself of a dissatisfied shareholder buys him ont at more than liquidating value, the loss to the remaining shareholders should be a corporate loss. 
produced. The receipt of its own shares merely marked its realization. In the case of the purchase of shares for cash at less than liquidating value, the income cannot be found in the consideration given by the corporation, but solcly in the fact that the remaining shareholders benefit.

That the benefit to the remaining shareholders is the sole basis for corporate income in such a case is demonstrated by the fact that no one would contend that the purchase of shares at less than liquidating value from all the sharcholders pro-rata produces corporate income. ${ }^{\text {s3 }}$ So if a single shareholder, whose shares were purchased to produce this "income," still owned some additional shares in the corporation, then under this theory the supposed curporate income should be reduced to the extent his remaining shares were benefited. The difficulty of computing liquidating, or even book values, on the day of every purchase, particularly between accounting periods, would in most cases make it impossible to apply this thcory.

To use the remaining shareholders' benefit as the sole test for corporate income alters the generally accepted concept of corporate income. In theory at least, the corporation is conducted for the benefit of all its shareholders, not some of its shareholders. The fact that one shareholder did not receive his share of accumulated income would, in some cases, be made the basis for taxing that income twice to the corporation. It is submitted that this is not a proper measure of corporate income or loss. If all a corporation can show for its activities is a benefit to some shareholders at the expense of others, it has had no corporate income or loss.

Judicial Developanent of Income Tax Aspects of Purchase and Sale by a Corporation of Its Own Shares

All of the cases so far analyzed which have held income or loss to be realized in transactions involving a corporation's own shares are those in which the shares were merely the medium of payment, either of an expense incurred by the corporation, or of income accrued to the corporation, or the consideration received in the sale or exchange by the corporation of appreciated or depreciated property. In all of these cases the income or loss was real in the sense that if settlement had been made in cash, or any property other than the corporation's own shares, it clearly would have been realized and recognized. It was not the fact that the corporation's shares were involved that created the income or loss.

53. But if all the sharcholders found the corporation's patents equally useful and paid lanages for infringement in shares, the corporation's yield or income from that patent has obviously increased to the same extent. 
The question of gain or loss from the purchase and subsequent sale by a corporation of its own shares presents an entirely different problem. It is whether income or loss can be created by a corporation solely by purchasing and then selling its own shares.

The earliest Treasury Regulations in 1918 first provided that if a corporation purchased its own shares and then sold them at a price in excess of cost, resold." 54

"such excess shall be returned as income for the year in which

For some reason, in the next Regulations issued, the interpretation was exactly reversed to provide:

"if a corporation purchases any of its stock and holds it as treasury stock, the sale of such stock will be considered a capital transaction and the proceeds of such sale will be treated as capital and will not constitute income of the corporation. A corporation realizes no gain or loss from the purchase of its own stock." os

-Later the last sentence was changed to read "purchase or sale" instead of "purchase" s6 and it remained thereafter unchanged for ten years. This provision, after its first and unexplained reversal, was approved in subsequent Bureau rulings, ${ }^{57}$ and though the taxpayers gave it an early test in the Board of Tax Appeals, it met with approval there. ${ }^{\text {s8 }}$

The Commissioner, after the Woods case, amended the regulation, partly for the purpose of making it clear that there were transactions in which a corporation acquired or issued its own shares in which thecorporation realized taxable gain or deductible loss. ${ }^{59}$ The Commis-

54. U. S. Treas. Reg. 33, Art 98 (1916 and 1917 Acts).

55. U. S. Treas. Reg. 45, Art 542 (I9r8 Act); U. S. Treas. Reg. 62, Art. 543 (1921 Act).

56. U. S. Treas. Reg. 65, Art. 543 (1924 Act) ; also U. S. Treas. Reg. 69, Art. 543 (1926 Act); U. S. Treas. Reg. 74, Art. 66 (1928 Act); U. S. Treas. Reg. 77, Art. 66 (1932 Act).

57. L. O. 1035, 2 CuM. But. 132, revised 3 CuM. BuLL 160 (1920); A. R. M. I14, 4 CUN. BuLl. I37 (I921).

58. Appcal of Cooperative Furniture $\mathrm{Co}_{0 .}, 2$ B. T. A. I65 (1925); Simmons and Hanmond Afanufacturing Co., I B. T. A. 803 (1925). The regulation was also at first applied to the purchase and sale by one member of an affiliated group of corporations of shares of another member where the sale did not break the affiliation. The Bonrd rul-ri that since the affiliation continued the group must be treated as a single taviny $r$ inging and selling its own stock on which no gain or loss can be realized. Ferilers Deposit National Bank, 5 B. T. A. 520 (1926) and conipanion cases United Drug Co. v. Nichols, 2I F. (2d) i6o (D. C. Mrass. I927); H. S. Crocker Co. 5 B. T. A. 537 (I926) and Interurban Construction Co., 5 B. T. A. 529 (1926) With the repidiation of the single taxpayer doctrine in consolidated returns in Woolford Realty Co. v. Rese, 226 U. S. 319 (1932), this rule was no longer applicd to such cases. Consolidated Utilities Co. v. Commissioner, 84 F. (2d) 548 (C. C. A. 5th, 1936); Commissioner v. General Gas and Electric Corporation, 72 F. (2d) 364 (C. C. A. 2d, 1934), cert. denicd, 293 U. S. $6 \mathrm{I} 8$ (1934); Van Camp Packing Co., Inc. v. Commissioner, 67 F. (2d) 596 (C. C. A. th $^{\text {th }} 1933$ ).

59. T. D. 4130, XIÍI-1 Cuม. BuLr. 36 (1934). 
sioner also entirely eliminated, instead of qualifying, the sentence which had caused so much confusion.

"A corporation realizes no gain or loss from the purchase or sale of its own stock"

But he went further than any of the then decided cases warranted and also removed the provision that no income was realized by the sale of "treasury stock." This pointed omission was coupled with the inclusion of the following sentence in the amended and subsequent Regulations:

"But if a corporation deals in its own shares as it might in the shares of another corporation, the resulting gain or loss is to be computed in the same manner as though the corporation were dealing in the shares of another." 60

It therefore was no surprise when rulings ${ }^{61}$ and cases commenced to appear in which the Bureau of Internal Revenue, for the first time since 1925 , contended that a corporation could realize taxable income from the purchase and subsequent sale of its own capital stock for cash. The Board in these cases, $R$. J. Reynolds Tobucco Company, ${ }^{62}$ E. R. Squibb and Sons, ${ }^{63}$ and First Chrold Corporation, ${ }^{64}$ approved the application of the amended regulation to such transactions occurring prior to I934. In its decisions it indicated that because of the Woods and similar cases there was no longer a complete restriction on the recognition of gain or loss arising in transactions by a corporation involving its own shares, that such transactions may not be solely capital transactions, that a corporation may treat its own shares as property, and if it buys this property and sells it for an amount in excess of cost, taxable gain will result.

Upon appeal of the Rey'nolds case to the Circuit Court of Appeals for the Fourth Circuit, ${ }^{65}$ that court held that the attempt by the Commissioner to change the regulation retroactively was unlawful and reversed the Board's decision. The Supreme Court approved this conclusion, as previously pointed out, but did not settle the question as to whether in years after 1934, under the changed regulation, taxable income could result from such transactions. ${ }^{66}$

60. U. S. Treas. Reg. 85 , Art. 22 (a)-I6 (Ig34 Act); similar provisions, U. S. Treas. Reg. 94, 10r, 103 (1036, 1938 Acts and Code).

61. G. C. M. I6651, XV-2 Cuas. Bult 130 (I035) ; G. C. M. I2955, XIII-1 Cux. Burt 105 (1934).

62. 35 B. T. A. 949 (1937).

63. 3 B B. T. A. 260 (1937).

6\% B. T. A memo. Op., Docket No. 81629 (1937).

65.97 F. (2d) 302 (C. C. A. 4th, 1938).

66. 306 U. S. I10 (1939). 
The Circuit Court of Appeals for the Second Circuit, in the appeal of the Squibb case, also pointed out that the regulation, before amendment, prevented the taxation as income of the excess of the sales price over the purchase price of its shares. But that court introduced a new theory to the effect that gain may arise from such a transaction if the shares were sold at a price higher than their "real" value at the time of sale. ${ }^{67}$ The court pointed out that where the corporation sells shares at their "real" value, if the corporate entity is explained from the standpoint of the shareholder group, then the old sharcholders have not profited because the value of their shares is unchanged, the group has merely enlarged with the incoming shareholder contributing his prorata share; but if he paid more than the "real" value the excess, even under the regulation, might be considered corporate income. ${ }^{68}$

The First Chrold Corporation case was also appealed and was affirmed by the Circuit Court of Appeals for the Third Circuit. ${ }^{89}$ This opinion introduced the "as if" theory of gain or loss. It recognized that in theory a corporation cannot own a share in itself, that a purchase of shares by it is a reduction of capital and that a sale of shares increases capital. But it pointed out that in fact corporations do buy and sell their own shares, like any other property and "as if" they were not the corporation's own shares, and that the excess of the sales price over the cost of the shares in such cases was taxable income.

Irrespective of the question as to whether the changed regulation can be made to apply to the year 1934 and subsequent years without a change in the law itself, ${ }^{70}$ a problem concerning the nature of taxable income, which has caused as much confusion as this, and which has been found to have at least three solutions, is not only interesting and challenging, but almost unique.

In arriving at these decisions, the courts have been referred by counsel to accounting theory and practice and these principles were discussed in some of the decisions. An apparent lack of agreement among accountants was found to exist, which alone made it necessary to disregard accounting practice as controlling. Since these cases were argued and decided, accountants have been debating the question of whether a

67. 98 F. (2d) 69 (C. C. A. 2 d, 1938).

68. The court made no attcmpt to cxplain what it meant by "real" value. It appears that it was referring to "liquidating" value, thus presenting the problem discussed at pages $947-949$ supra.

69. $97 \mathrm{~F}$. (2d) 22 (C. C. A. 3d, 1938), rczd, 306 U. S. 117 (1939).

70. In National Home Owners Service Corp., 39 B. T. A. 753 (1939), the Board held that the Commissioner had no power to change the regulations to be applied to the years I934 and I935. To the same effect for the year 1937 sce National Manufacture and Stores Corp. v. Allen, D. C. M. D. Ga., November 2, 1940. This case also points out that when shares were purchased for retirement, though the corporation later decided to reissue them, it had not dealt in its shares as it would in the shares of another corporation. 
corporation can realize income or loss from buying and selling its own shares, and now for the first time it can be said that accounting opinion on this question is practically unanimous in its conclusions and should not now be overlooked in an attempt to solve the similar income tax problem.

It is undoubtedly true that the popular concept of income has had its effect on the legal concept, but

"To a considerably greater extent, accounting practice serves to condition and to modify the concept of income. . . . There is likely to be a gradual cross-fertilization betwcen the income tax decisions and accounting principles, as each group of specialists comes to know the other's theories and results." 71

\section{Recent Accounting Conclusions on Incoare from Sale of Treasury SHares}

The Executive Committee of The American Accounting Association, as a starting point on the codification of accounting practice and for the purpose of inviting criticism and discussion, published a Tentative Statement of Accunting Principles Underlying Corporation Financial Statcments and set forth the following proposals relating to the treatment of the purchase and sale of "treasury shares":

"The income account of a corporation should not include credits or charges resulting from profits or losses on transactions involving the issuance, purchase, or retirement of its own stock. - . Paid-in capital consists of amounts received for shares issued: capital stock, paid-in surplus, gains from the sale of reacquired shares and from the retirement of reacquired shares purchased at a discount. . . . Earned surplus should include no credits from transactions in the company's own stock . . .."72

It is significant to note that in this first formulation of accounting principles reference is made to "profits or losses" and to "gains" on transactions involving the issuance, purchase, or retirement of its own shares; at the same time, it is pointed out that such "profits" and "gains" should not be included in corporate income or in earned surplus. The authors, in a subsequent statement, make clear their meaning: that what is commonly referred to as "gain," "profit," or "loss" from

71. MAgill, TAxable INCONe (1936) 19.

72. (I936) II ACCTG. REv. 187. Accountants have recently directed their attention to the formulation of accounting principles, but unlike the operation of the American Law Institute ar:d the formulation of its Restatements of I,aw, general principles and practices are haing discussed and codified through three principal sources, The American Institute of Accountants, The American Accounting Association, and the Securities and Exchange Commission, all of which are now consulting in the formulation of accounting standards. 
such transactions should now uniformly be accorded the more rational treatment of exclusion from income ${ }^{73}$

Later the New York Stock Exchange raised a question with the special committee of the American Institute of Accountants on Cooperation with Stock Exchanges, regarding the treatment of the purchase and subsequent sale by a corporation of its own shares. The following decision was reached:

"Your committee believes that while the net asset value of the shares of common stock outstanding in the hands of the public may be increased or dccreased by such purchase and retirement, such transactions relate to the capital of the corporation and do not give rise to corporate profits and losses. Your committee can sce no cssential difference between (a) the purchase and retirement of a corporation's own common stock and the subsequent issue of common shares, and (b) the purchase and resale of its own common stock." 74

The American Institute of Accountants recently published $A$ Statement of Accounting Principles, prepared by Sanders, Hatfield and Moore, for the purpose of evoking discussion. This report concludes that surplus arising from the sale of reacquired shares is in general to be regarded as paid-in surplus, "but when such profits or losses occur in small amounts, . . . it may be treated as earned surplus." ${ }^{75}$ The discussion relating to this portion of the Statement showed agreement almost without exception. The principal criticism seemed to be that the authors should have even suggested that inconsequential "profits" on treasury shares be included in earned surplus. ${ }^{76}$

And finally, the Securities and Exchange Commission ruled on the precise question of corporate income from buying and selling its own shares:

“. . . from an accounting standpoint, there appears to be no significant difference in the final effect upon the company between (I) the reacquisition and resale of a company's own common stock and (2) the reacquisition and retirement of such stock together with the subsequent issuance of stock of the same class.

"It is recognized that when capital stock is reacquired and retired any surplus arising therefrom is capital and should be accounted for as such and that the full proceeds of any subsequent issue should also be treated as capital. Transactions of this nature do not result in corporate profits or in earned surplus. There

73. Paton and Littleton, An Introduction to Corporate Accounting StandARDS (1940) II 5 .

74. (1938) 65 J. AсcTCY. 417.

75. At page 90 .

76. Comments of Paton, A Statcment of Accounting Principles (1938) $65 \mathrm{~J}$. Accrcy. 206; Watson, Prisciple's Related to Trecsiry Stock in PArers ox Accounting Principles and Procsdire, American Institute Acoountants (i938) 31. 
would seem to be no logical reason why surplus arising from the reacquisition of the company's stock and its subsequent resale should not also be treated as capital." 77

Consistent with this ruling, the latest regulations of the Securities and Exchange Commission now provide that any such "profits" shall not be included in the net income of the corporation. ${ }^{78}$

In view of the recent steps towards agreement ${ }^{70}$ on the part of accountants that no income may be derived from a corporation's purchase and sale of its own shares, it would be unfortmate for future income tax cases, involving the same question, to add yet another variance between generally accepted accounting principles and income tax treatment, unless such a difference is required by the law, or in the development of a co-ordinated income tax structure.

Is the "Profit" or "Loss" on the Sale of Treasury Shares Real?

Bui, argues the Board of Tax Appeals, to ignore the obvious "profit" if a corporation buys and sells its own shares as it would any other property presses accounting theory too far.

"That such a regulation is based on a false premise; that it elevates to a position of authority a concept which runs counter both to reason and ordinary business judgment; that it prefers a highly artificial interpretation to the ustral rationale of normal minds would seem to be 'weighty reasons' for dethroning such a regulation or practice." 80

The Supreme Court decisions have made clear its refusal to enter into "refinements" and its seareh, instead, for the "commonly understood meaning" of the word income. If the accountants' conclusions are highly artificial and contrary to reason and ordinary business judgment, it is uscless to try to force their adoption in income tax cases. These conclusions should now be tested in the light of "reason and ordinary business judgment."

A simple illustration will serve to make clear the nature of the "gain" or "Ioss" which a corporation is supposed to realize from buying and selling its own shares. Suppose that a corporation is formed for the sole purpose of investing in securities, including its own sliares. $A, B$, and $C$, the orizinal subsertibers, cach pay in $\$ 1, n \infty 0$ for 10 shares

77. SEC Accountirg Series Release No. 6.

78. Reg. S-X, Art. 5-Rule 5.03.

79. But see Mlontgomery, Dralings in Trcasury Stock (1938) 65 J. Accrcy. 46.

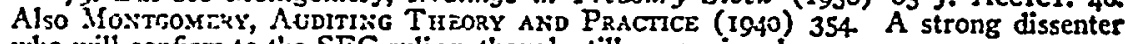
who will confirm to tir SEC ruling, though still unconvinced.

So. R. J. Reynolis Tobacco Co, 35 B. T. A. 949, 964-65 (1937). 
of its stock of a par value of $\$ 100$. The corporation uses $\$ 2,000$ of the cash so received to buy stock of various corporations, the market value of which is constantly fuctuating. A later offers to sell his shares to the corporation, and the directors, believing that they are or will be worth more, purchase them for the issue price, intending to sell them at a "profit" as soon as possible and, in the meantime, holding them as treasury shares and even showing them as an "asset" on the corporation's balance sheet. Later as the market value of the corporation's investments continues to fluctuate, the directors are able to sell these treasury shares to $R$ for $\$ 1,300$, thus realizing $\$ 300$ of "profit."

It is obvious that the corporation is $\$ 300$ "richer" than it was before. It seems clear to some that, the transaction having been designed to produce profit and actually causing an increase in corporate net assets, no refinements or artificial concepts should stand in the way of its taxation.

But to continue the illustration, as the fortunes of the corporation change, $B$ and $C$ successively desire to liquidate their interests at $\$ 1,000$ each. The same procedure is repeated, with the same confidence and intent on the part of the directors, and the treasury shares are later sold to $S$ and to $T$ for $\$ 1,300$ each, thereby realizing $\$ 600$ more of "profit" The corporation now holds all its original investments with the cost basis of $\$ 2,000$ and has in addition $\$ 1,900$ of cash. On the other hand, it has its original capital account of $\$ 3,000$ still intact, and a $\$ 900$ "earned" surplus as well.

Now assuming that it is thereafter determined to liquidate the corporation and the investments are sold at their market value, which now is cost, as a result of which there was no gain or loss from that phase of its corporate activities. Disregarding any possible expenses and the income tax which may have been paid on the $\$ 900$ of "income," the corporation will then have $\$ 3,900$ cash to distribute to its three shareholders, $R, S$, and $T$, who receive $\$ \mathrm{r}, 300$ each in liquidation.

$A, B$, and $C$ have each recovered their exact inrestment, $\$ I, \infty 00$, $R, S$, and $T$ have each recovered their exact investment, $\$ 1,300$, no more and no less. But the corporation has received income of $\$ 900$ ! What sort of corporate income is this which disappears when an attempt is made to distribute it to its sharcholders, for whose benefit the corporation is operated and who shutuld receive all of its income? ${ }^{81}$ The answer is that it is not corporate income at all, under either the economic or accounting concept of income, or under the common or business interpretation.

81. If the "income" of $\$ 000$ yias distributcd as a dividind then the shareholders would have a corresponding loss on liquidation. 
We have already assumed conditions most conducive to the production of income, if income can be so manufactured. The shares were treated as "treasury shares," and carried as assets. There was no intent to cancel the shares, but on the contrary the expectation of selling them at a "profit." They were sold at a "profit."

It follows that if three such transactions produce no corporate income, no one of the transactions could have produced corporate income. Considering only the first purchase of $A$ 's shares and their sale to $R$, if the corporation then liquidated its investments at cost, it would have $\$ 3,300$ to distribute pro rata. $B, C$ and $R$ now would receive $\$ 1,100$ each, a loss of $\$ 200$ for $R$ and a gain of $\$ 100$ to $B$ and $C$. Again it seems evident that the mere fact that some shareholders may eventually profit by the transaction, does not produce corporate income. Their profit is merely the loss of another shareholder, not the result of corporate income. Even if we should consider that in purchasing $A^{\prime} s$ stock in the hope of selling it at a profit, the directors were in effect acting for the shareholders, $B$ and $C$, the indirect benefit to $B$ and $C$ from the transaction is $\$ 200$ and not $\$ 300$. But such a method of computing corporate income from these transactions has never been suggested.

The foregoing analysis also discloses the fallacy in the theory of the Circuit Court of Appeals for the Second Circuit set forth in the Squibb case. Assuming that the "real" value of the corporation's shares was only $\$ 1,200$ when sold to $R, S$, and $T$ for $\$ 1,300$. Under that court's theory $\$ 300$ of income would have been produced. But this "income" also disappears when the corporation attempts to distribute it to its beneficial owners, the shareholders.

If the purchases and sales were made on a stock exchange, the only additional factor thus presented is a purchase and sale through agents, with the principals undisclosed. The results to the corporation, lowever, remain the same. Nor does an increase in the size of the corporation, or the added factor of corporate income or losses from other transactions, change in any respect the conclusions obtained from the simple illustration.

The result is always the same whether the treasury shares are sold at a "loss," whether they are purchased at. above, or below the price at which they were issued, their present book value, their present market value, or their present liquidating value. Considering any combination of these transactions, the shareholders, present and past, taken as a whole can have no final net gain or loss. The income of one is the loss of another. But no corporate gain or loss can result. It is impossible for a corporation to buy and sell its own shares as it would the shares 
of another corporation, and to do so with the same possibility of gain or loss.

But it well may be said, the profit at the time appeared to be not only real but realized. The answer is that each ale by the corporation of its treasury shares at a price in excess of the purchase price, was made possible either because of an actual increase in net assets through income accumulated since the purchase, or because of a more favorable market appraisal of the underlying asset values or possibilities of future income. To tax the corporation on such an increase both at the time of the sale of its treasury shares and again zipon the realization of the appreciation in asset values or the receipt of increased income, is in effect to tax the same income twice to the corporation. ${ }^{82}$

The illusion of profit or loss from treasury shares transactions is partly attributable to the convention of income taxation and accounting (which creates most problems), namely, the necessity for artificially stopping and measuring each year the flow of income and expense of a continuous business enterprise. This has caused the emphasis here to be placed on the current effect of a given transaction and not on the final outcome. Despite the difficulties presented by the requirement of annual accounting, it is certainly true that the final income of a corporation should equal the sum of its annual parts.

\section{Conclusion}

The corporation, as a taxable entity, is a business enterprise conducted for the benefit of the contributors of owner capital, the shareholders. The reccipt of owner capita! by the corporation or its return to the owners does not create income or loss to the corporate entity. Nor does corporate income or loss arise from the fact that the amount of new capital contributed from time to time may be disproportionate to the value of the interest in the total ownership equity, secured by such new capital investment; or from the fact that distributions of such capital to withdrawing shareholders are not equal in value to the then interest of the withdrawing shareholder in the total ownership equity. Since such inequalities arise solely out of transactions with the shareholders as contributors of owner capital, they can only result in a shifting of ownership equities between shareholders, in the form of a contribution by one shareholder or group of sharcholders to another, but cannot result in corporate incone or loss.

82. See Note, Fedcral Tazalion of Trcasury Stock Transactions (1938) 6 U. or Cirr. I. Rex. 02; Watson, Principles Related to Trecsury Stock in PAPERs on ACcounting Ppinciples and Procedure, Aserican Institute of Accountants (1938) 34 
Corporate income or loss may arise from all transactions other than those related merely to the securing or returning of ownership capital. If a corporation enters into business transactions of any other character with its shareholders, income or loss may be realized by the corporation to the same extent as if they were not also the residual beneficiaries of corporate income.

Further, it is possible for a corporation in one transaction to be dealing with a person, both as a contributor of owner capital and as an "outsider." In such cases the corporation may realize income or loss. Thus in one transaction a corporation may deal with a person as an employee who has rendered services and earned compensation and at the same time as a contributor of the amount thereof to the corporation's capital. The same person may in one transaction be both a retiring shareholder and also a purchaser of corporate assets at a price above or below the corporation's basis; or one who is obligated to pay damages, or rent, or interest to the corporation; or a debtor of the corporation wishing to compromise the claim. In all such cases the shares of the retiring shareholder are merely the medium of payment.

The plase of the transaction relating to his status as a contributor of owner capital does not result in corporate income or loss. The corporate income or loss arises out of and is measured by the other phase of the transaction, the corporation's dealings with the shareholder as an outsider. If this dual aspect is missing in a transaction and the corporation deals with the shareholder solely as a prospective, present, or retiring contributor to the capital of the corporation no corporate income or loss may ever result.

It is impossible, however, for a corporation in buying and selling its own shares, no matter what its intent, to be dealing with the shareholders so retired or created other than solely as shareholders. It is for this reason that corporate income or loss can never result from any such transactions. 